\title{
An Updated Assessment of Personal Protective Order Statutes in the United States: Have Statutes Become More Progressive in the Past Decade?
}

Violence Against Women 2018, Vol. 24(7) 816-842

(C) The Author(s) 2017

Reprints and permissions: sagepub.com/journalsPermissions.nav DOI: $10.1177 / 1077801217722237$ journals.sagepub.com/home/vaw

@SAGE

\section{Tara N. Richards', Alison Tudor ${ }^{2}$, and Angela R. Gover ${ }^{3}$}

\begin{abstract}
The Personal Protection Order (PPO) is one civil intervention all states provide to victims of domestic violence; however, each state varies widely in who can access PPOs, what protections are included in PPOs, and how they are enforced. Given the many changes to state PPO statutes over the last decade, this research replicates and updates Dejong and Burgess-Proctor's research on PPOs' victim-friendliness (using states' 2003 PPO statutes) by examining states' 20I4 PPO statutes. Findings suggest that states have become more victim-friendly with most states ranking in the highest category of victim-friendliness. Implications for policy and practice are discussed.
\end{abstract}

\section{Keywords}

domestic violence, victim empowerment, violence against women

\section{Introduction}

Domestic violence is a serious public health concern that will affect one in four women and one in seven men in their lifetime (Black et al., 2011). Domestic violence includes physical, psychological, financial, or sexual harming behavior between current or

\footnotetext{
'University of Baltimore, MD, USA

${ }^{2}$ Alliance for Community Transformations, Mariposa, CA, USA

${ }^{3}$ University of Colorado Denver, USA

\section{Corresponding Author:}

Tara N. Richards, School of Criminal Justice, University of Baltimore, 1420 N. Charles St., LAP 5 I9, Baltimore, MD 2I20I, USA.

Email: trichards@ubalt.edu
} 
former intimate partners (Alaggia, Regehr, \& Rishcynski, 2009; Pender, 2012). Domestic violence can occur within any intimate partnership, including heterosexual and same-sex relationships; married, unmarried, or divorced couples; within dating relationships; and between couples who have a child in common (Gover, 2011). Some research, however, suggests that domestic violence is perceived to be more serious among heterosexual couples and when the victim is female (Russell, Chapleau, \& Kraus, 2015).

Domestic violence is associated with significant consequences for the individual experiencing the violence, the family unit, and society as a whole (Coker et al., 2002; Max, Rice, Finkelstein, Bardwell, \& Leadbetter, 2004; Stewart, Vigod, \& Riazantseva, 2016). Children exposed to domestic violence have an increased risk for a range of negative outcomes such as developmental issues (Wolfe, Crooks, Lee, McIntyreSmith, \& Jaffe, 2003), poor health outcomes (Bair-Merritt, Blackstone, \& Feudtner, 2006), and experiencing domestic violence later in their own romantic relationships (Gover, Kaukinen, \& Fox, 2008). Domestic violence is the largest cause of injury for girls and women aged 15-44 years and domestic violence-related homicide is a primary cause of death for women worldwide (Mills, 1998; Novello, Rosenberg, Saltzman, \& Shosky, 1992; Stout, 1989; World Health Organization, 2013). In addition, domestic violence-associated costs, including the law enforcement response, judicial engagement, health care needs, loss of productivity, and the loss of life, exceed $\$ 8.3$ billion each year (Max et al., 2004). Further economic consequences include eight million missed days of work, a loss of 32,000 full-time jobs, and a loss of 5.6 million days of household productivity as a direct result of domestic violence (National Center for Injury Prevention and Control, 2003).

Given the prevalence and consequences of domestic violence, advocates and proponents of the feminist and women's movement(s) have worked to develop responses to minimize the harm associated with domestic violence and prevent revictimization. Civil Personal Protection Orders (PPOs) represent one such response to domestic violence (Davis \& Smith, 1995; Ko, 2002; Voris, 1991) with approximately one million victims of domestic violence seeking protection orders annually (Fleury-Steiner, Miller, Maloney, \& Postel, 2016; Tjaden \& Thoennes, 2000). Although PPOs have been utilized nationwide since 1994, over the past 30 years states' PPO statutes have evolved to comply with new federal legislation to include broader definitions regarding the types of domestic relationship covered by PPOs and to provide more extensive provisions for victims. Further advancements in PPO legislation include waiving/ reducing filing fees, providing victim filing assistance, and address confidentiality programs, among others (Eigenberg, McGuffee, Berry, \& Hall, 2003). In this vein, DeJong and Burgess-Proctor (2006) comprehensively examined the statutory language of PPO laws from 2003 to identify the range of provisions included in PPO statutes and determine the level of "victim friendliness" of statutory language across states. The current study replicates DeJong and Burgess-Proctor's work and provides a 10-year update, and in some cases, an expansion, of the status of statutory PPO language across the United States. 


\section{Literature Review}

\section{PPOs}

The term PPO is not uniformly used across the country. PPOs are also known as civil protection orders, permanent restraining orders, protection from abuse orders, or interim protection orders (Brame, Kaukinen, Gover, \& Lattimore, 2015). These orders are ". . . signed by a judge to restrict access of one person to another person, property, children, family, or live-in friends of another person" over a designated period of time (Fernandez, Iwamoto, \& Muscat, 1997, p. 40). PPOs are intended to prohibit an abuser from having contact with a victim to prevent subsequent domestic violence from occurring (Fleury-Steiner et al., 2016; Miller, 2004). While PPOs are technically civil orders, violations of PPOs may result in criminal sanctions ranging from misdemeanor to felony charges, depending on the state (Fritsche, 2014).

PPO statutes vary widely from state-to-state (Logan \& Walker, 2009) across a range of criteria. For example, states' PPO statutes may differ on the type of provisions made available in the PPO, the types of petitioner-respondent relationships that are eligible for a PPO, the availability of assistance from the court in filing paperwork for a PPO, penalties for PPO violations, and treatment requirements for offenders (DeJong \& BurgessProctor, 2006; Eigenberg et al., 2003). As such, the experience of seeking a PPO in one state can be vastly different than the experience of seeking one in another state.

While the main purpose of a PPO is to keep the offender from contacting the victim, PPOs have a number of additional potential provisions afforded to victims who obtain them (Candela, 2016; Goodman et al., 2016). Provisions may include specifying the number of feet that the offender must remain away from the victim, requiring the offender to move out of a residence shared with the victim, and requiring the offender to relinquish any firearms in their possession (DeJong \& Burgess-Proctor, 2006; Eigenberg et al., 2003; Voris, 1991). In some states, PPOs include provisions for division of property, financial support, and custody and visitation stipulations (Eigenberg et al., 2003; National Center on Protection and Full Faith and Credit, 2010).

The federal Violence Against Women Act of 1994 (VAWA) aimed to address the lack of legal response to violence against women across the United States. VAWA recognized that PPOs and their accessibility were crucial to enhancing safety for women and children. However, many of the VAWA mandates were outlined as recommendations that states could choose to adopt into their state laws. With this discretion, states created very different laws regarding domestic violence, some even contradictory to one another. For example, victims in Pennsylvania do not have to serve their attacker with restraining order papers, while in California, the law is the exact opposite-victims must deliver their own paperwork to the defendant.

\section{The PPO Process}

The process of obtaining a PPO typically includes two stages. The first step involves applying for a temporary protective order, which can be obtained through criminal or 
civil court depending on the state (Chaundhuri \& Daly, 1992; DeJong \& BurgessProctor, 2006; Grau, Fagan, \& Wexler, 1985; Kaci, 1992; Zoellner et al., 2000). Temporary protection/protective orders, temporary restraining orders, or ex parte orders are granted immediately if there is reasonable proof of abuse (Ko, 2002). For a PPO to be issued, a "preponderance of the evidence" must show that the respondent has committed an act of violence against the petitioner ("victim," "plaintiff," or "protected party") that meets the legal definition of domestic violence in that jurisdiction. The civil system requires a lower burden of proof than what is mandated for conviction in criminal court (Lucken, Rosky, \& Watkins, 2015).

The second step of the PPO process is an evidentiary hearing about which the abuser must be notified and both the victim and offender must attend. At this hearing, the victim and the abuser may give testimony in regard to the allegations of abuse. The purpose of this hearing is to determine if the temporary order was justified and whether it should be extended to the allowable statutory maximum time period (i.e., if a permanent PPO should be granted; Chaundhuri \& Daly, 1992; DeJong \& Burgess-Proctor, 2006; Grau et al., 1985; Kaci, 1992; Zoellner et al., 2000).

Prior research suggests that many victims have difficulty accessing PPOs (Hien \& Ruglass, 2009; Logan, Shannon, \& Walker, 2005). Victims seeking PPOs may experience procedural barriers such as confusion over the required paperwork, the court process, or the associated costs (DeJong \& Burgess-Proctor, 2006; Eigenberg et al., 2003). To help overcome these obstacles, some states allow the court clerk to provide minimal nonlegal assistance to the petitioner (DeJong \& Burgess-Proctor, 2006; Eigenberg et al., 2003). A filing fee is typically required for many court documents; however, some states have waived filing fees for PPOs to reduce financial barriers to victims' safety (DeJong \& Burgess-Proctor, 2006; Eigenberg et al., 2003). Many victims face the additional obstacle of possible retaliation from their abusers for seeking a PPO (Lucken et al., 2015). Retaliation may include subsequent physical, psychological, or sexual abuse or behavior that puts the victim in fear.

\section{PPO Effectiveness}

Prior research indicates that PPOs are the most common legal remedy used by victims to respond to domestic violence (Fleury-Steiner et al., 2016; Goldfarb, 2008; Logan \& Walker, 2009; Ooms, 2016). PPOs aim to deter future violence, threats, or intimidation and increase victim safety (Meloy, Cowett, Parker, Hofland, \& Friedland, 1997). PPOs may also provide a pathway to assistance for victims who do not want to pursue a criminal case or whose experience with violence does not meet the criteria for criminal action (Chaundhuri \& Daly, 1992; Grau et al., 1985; Weissman, 2007). PPOs may also supply victims with increased access to social services, shelters, or counseling (DeJong \& Burgess-Proctor, 2006; Fischer \& Rose, 1995).

Previous studies on the impact of PPOs offer mixed results (Goodman et al., 2016). PPO effectiveness is usually measured according to PPO violations and victims' perceptions of PPO effectiveness (Logan \& Walker, 2010). Regarding revictimization, research demonstrates that PPOs are not a panacea that works for every victim, every 
time (Chaundhuri \& Daly, 1992). Studies show that anywhere from $35-60 \%$ of victims with a PPO experience revictimization (Chaundhuri \& Daly, 1992; Grau et al., 1985; Haggård, Freij, Danielsson, Wenander, \& Långström, 2017; Harrell \& Smith, 1996; Joice, 2006; A. R. Klein, 1996; Meloy et al., 1997). There is also some evidence that violence may escalate after a victim has obtained a PPO (Berk, Berk, Loseke, \& Rauma, 1983; Burgess et al., 1997; Joice, 2006, but see A. R. Klein, 1996).

At the same time, prior studies indicate positive victim perceptions of PPOs. Logan and Walker (2010) reported that the benefits of civil orders include the lower level of proof required in the civil system during court, quicker punishments for violations of civil orders, and the potential for the PPO process to serve as a source of empowerment for victims. For example, Fischer and Rose (1995) found that $91 \%$ of victims with PPOs felt that the PPO was a good decision for them, $89 \%$ felt more in control of their relationships, and $98 \%$ felt more in control of their lives. Keilitz, Hannaford, and Efkeman (1997) found that 6 months after receiving a PPO, 85\% of survivors reported life improvement, $90 \%$ felt better about themselves, and $80 \%$ felt safer. Furthermore, Harrell and Smith (1996) reported that $79 \%$ of victims in their sample felt that the PPO sent a message to the abuser that the violence was wrong and $62 \%$ of victims felt that the PPO was a good punishment for the abuser. Finally, Durfee (2009) found that victims who obtained a PPO reported access to one additional social service provider on average than victims who did not obtain a PPO. And victims report that after receiving a PPO, law enforcement response to calls for service regarding their abuser were timely and supportive (Chaundhuri \& Daly, 1992; Grau et al., 1985).

\section{The Dejong and Burgess-Proctor Study (2006)}

DeJong and Burgess-Proctor (2006) examined aspects of the 2003 PPO statutes for all 50 states and the District of Columbia in regard to the PPO's "victim friendliness." DeJong and Burgess-Proctor conceptualized victim-friendliness using four domains: (a) adherence to stipulations of VAWA, (b) the ease of the PPO's administrative process, (c) the inclusiveness/exclusiveness of the petitioner-respondent relationship types eligible for a PPO, and (d) the types of punishments utilized by states in response to PPO violations. States were assigned scores for each domain, which were summed to create an overall victim-friendliness score. Dejong and Burgess-Proctor expected progressive states whose legislatures were supportive of crime victims' rights overall to have language in their PPO statutes demonstrating the state's priority of safety for victims and support during the PPO-seeking process. In addition, DeJong and BurgessProctor developed the following cut points (low $=4.0-5.5$, medium $=6.0-7.0$, and high $=7.5-10.0)$ for categories of victim-friendliness.

Results demonstrated that in 2003, states' victim-friendliness scores ranged from 5.5-10; the median was 6.0. Furthermore, 17 states ranked in the highest category for victim-friendliness, 19 ranked in the middle category, and 15 states and the District of Columbia ranked in the lowest category. Substantial regional trends were identified, with midwestern states ranking in the highest category and southern states ranking in the lowest category; however, several individual states represented regional "outliers" 
such that they substantially deviated from other states in the region regarding PPO victim-friendliness. For example, while Missouri's PPO statute had the highest overall score for victim-friendliness (score of 10), Ohio ranked in the lowest category with a victim-friendliness score of 5.5. In addition, while Florida ranked in the highest category (score of 8.5), South Carolina ranked in the lowest category (score of 4.0) (DeJong $\&$ Burgess-Proctor, 2006).

\section{The Present Study}

A decade ago, DeJong and Burgess-Proctor's (2006) research provided a comprehensive and theoretically grounded assessment of states' 2003 PPO statutes' provisions and established baseline data for PPOs' "victim-friendliness." The present research replicates DeJong and Burgess-Proctor's research to present an updated analysis of 2014 statutes and offer analyses regarding the trends in states' PPO statutory language over this 10 -year period.

Utilizing DeJong and Burgess-Proctor's (2006) coding scheme, each state's 2014 PPO statute was analyzed and a victim-friendliness score was calculated. States were then ranked according to DeJong and Burgess-Proctor's same categories of low, medium, and high (low: 4.0-5.5; medium: 6.0-7.0; high: 7.5-10.0). States' 2014 rankings are reported here and then states' 2014 and 2003 rankings (as reported by DeJong \& Burgess-Proctor) are compared. Key components of states' 2014 victim-friendliness scores are discussed in regard to the domestic violence literature and relevant public policy, and where possible, new advances in states' PPO statutes since DeJong and Burgess-Proctor's work are presented and discussed.

This research informs the literature, policy, and practice in two primary ways. First, this study contributes to the understanding of how states' PPO statutes have changed over time. Policy makers and advocacy groups may utilize advances in PPO language in other states or national trends when considering amendments to their state's PPO statute. This study also has important implications for research. By identifying current patterns in PPO statutes, violence against women scholars are better positioned to examine which PPO provisions are related to positive outcomes for victims, and which may have little to no impact, or even unintended consequences.

\section{Method}

\section{Data}

The present analysis includes an assessment of PPO statutes from all 50 states and Washington, D.C. Each state adopts new statutes at different times during the year with the majority of changes taking effect in January. For the present study, PPO statutes were obtained through states' websites from April 1, 2014-August 31, 2014, and thus reflect information included in statutes up to the end of August 2014. The majority of states' PPO statutes were found in their entirety in one location (e.g., family law or criminal law); however, some states' PPO statutes also referenced sections of other 
statutes. For example, information relevant to New York's PPO statute is found in family and criminal sections of the statute. Following the methodology of DeJong and Burgess-Proctor (2006), data for the current analyses focused solely on statutory language; no case law or notes were examined.

\section{Coding Scheme}

Given that the present study aims to replicate and update DeJong and Burgess-Proctor's (2006) research, the coding scheme and analytic plan adhere to the strategies utilized in their earlier work. Specifically, the analysis focused on the four domains DeJong and Burgess-Proctor used to conceptualize victim-friendliness: (a) adherence to VAWA, (b) the petitioner-respondent relationship, (c) the administrative process, and (d) punishing PPO violations. The significance of each domain and a detailed explanation of the 11 variables included in the domains as presented by DeJong and BurgessProctor are provided below (also see Appendix).

Violence Against Women Act (VAWA). The Violence Against Women Act (VAWA, 1994) included several provisions relevant to states' PPO statutes. First, under VAWA states were required to include language recognizing the full faith and credit of foreign PPOs (i.e., PPOs from other states or tribal land). As described by DeJong and BurgessProctor (2006), the full faith and credit provision is important for two primary reasons. First, the full faith and credit provision mandates that a violation of a foreign PPO must be considered a violation by the courts of the state or tribe where the violation occurs, and the offender should also be punished according to the laws of that state or tribe. Second, the provision mandates that PPOs issued in one state must be enforced in other states without any additional registration process. Because federal law (e.g., VAWA) supplants state law, it is not inherently necessary for states to include language regarding full faith and credit in their PPO statutes; however, DeJong and BurgessProctor suggested that many state-level criminal justice system actors may not be as familiar with federal law as they are with their own state law, so explicitly stating these provisions in statutory language is seemingly important for consistent enforcement of PPOs. The full faith and credit provision was assessed in regard to the specificity of information included in the PPO where greater specificity was considered more victim-friendly $(1.0=$ foreign orders were enforced, $0.5=$ foreign orders were enforced upon registration/implied, $0.0=$ not stated).

Second, under VAWA mutual PPOs were not accepted outside of the state where they were issued unless there was proof of mutual violence. As discussed by DeJong and Burgess-Proctor (2006), mutual PPOs do not specify which party is the victim and which party is the offender, so in essence, they insinuate a shared responsibility for the violence. In addition, because mutual orders are indeed mutual, if one party violates the order, both parties could be held responsible for the violation, increasing the likelihood that victims will be punished for seeking assistance. The context in which a state accepts a mutual protective order was assessed and states requiring proof of mutual violence were identified as more victim-friendly $(1.0=$ state requires proof of mutual 
violence for acceptance, $0.5=$ requirement of proof is implied or ambiguous, $0.0=$ not stated).

Petitioner-respondent relationship. At their inception, PPOs could only be accessed by women who were actively seeking a divorce from their husband (Grau et al., 1985). According to DeJong and Burgess-Proctor (2006), over time PPO statutes have become more inclusive and now comprise language that allows access to heterosexual male victims and in some cases victims of same-sex couple violence. PPO statutes were examined for the use of gender-neutral language $(1.0=$ yes, $0.0=$ no $)$ and definitions that include violence between same-sex partners $(1.0=\mathrm{yes}, 0.0=$ no). Statutes were considered the most victim-friendly if the language provided PPO access to male, female, and same-sex victims.

Administrative process. DeJong and Burgess-Proctor (2006) identified that the legal system itself may serve as a barrier to seeking PPOs if victims perceive the application and/or court process as too complicated to navigate and/or may be confused about the associated court fees. To help navigate the PPO process, victim-friendly states allow the court clerk to provide assistance to the petitioner $(1.0=$ yes, $0.0=$ no or not stated $)$. In addition, it is common for courts to require a fee to process documents that are filed in the court, including PPO applications. However, many victims of domestic violence are economically disadvantaged (Gustafsson, Cox, \& Family Life Project Key Investigators, 2016) and/or are economically dependent on their abuser (Özçakar, Yeşiltepe, Karaman, \& Ergönen, 2016). DeJong and Burgess-Proctor (2006) found that some states waive the filing fees for PPO processing and/or charge the filing fees to the respondent in cases where the court finds ground to issue a PPO. The current study examined state statutes to determine the status of filing fees $(1.0=$ fees waived, $0.5=$ fees charged to respondent, $0.0=$ not stated/fees charged). States that waived filing fees were considered to be the most victim-friendly.

Furthermore, DeJong and Burgess-Proctor (2006) noted that historically, the PPO process was only accessible to victims who also participated in criminal proceedings against their abuser. However, there has been growing recognition that many victims of domestic violence do not want to be involved in the criminal justice system (Ko, 2002; Waul, 2000), but do want access to protection through the civil process. In addition, some victims' experiences with violence may not meet the threshold for criminal charges (Candela, 2016), but they may still benefit from a PPO. As a result, state statutes were examined to determine if a victim could receive a PPO outside of filing criminal charges $(1.0=$ yes, $0.0=$ no $)$.

The ability for a victim to keep their address confidential during the PPO process was also assessed. Address confidentiality may be important in cases where a victim has fled their abuser and is in continual fear for her or his safety. Furthermore, victims who are planning to leave their abuser may not want to begin the PPO process if they are required to keep an up-to-date home address on file with the court that could be shared with their abuser. State statutes were examined to determine if the victim's address could remain confidential $(1.0=$ yes, $0.0=$ no $)$ and were considered more victim-friendly if confidentiality was provided. 
Punishing violations. Finally, DeJong and Burgess-Proctor (2006) noted the importance of offender accountability upon PPO violation. Their coding scheme included three types of consequences associated with a PPO violation: criminal justice sanctions, therapeutic treatment programs, and weapons restrictions. First, state statutes were analyzed to determine the criminal justice implications for a violation $(1.0=$ any violation is a felony, $0.5=$ first violation is a misdemeanor, $0.0=$ misdemeanor on each violation). According to DeJong and Burgess-Proctor, states were more victim-friendly if a violation of a PPO was deemed a felony. Second, the role of counseling as a response to violations was captured $(1.0=$ requires counseling/treatment upon violation, $0.5=$ allows for counseling/treatment after violation or as a provision within PPO, $0.0=$ not stated). DeJong and Burgess-Proctor assessed states as more victimfriendly if they required batterer intervention treatment programs (BIPs) or another form of counseling upon violation. Finally, given the documented role of firearms in domestic homicide (Bailey et al., 1997; Campbell et al., 2003; Price \& Payton, 2016; Zeoli, Malinski, \& Turchan, 2016), PPO statutes were examined to assess the restriction of weapons upon the issuance of a PPO $(1.0=$ mandates the surrender of weapons, $0.5=$ allows for the surrender of weapons, $0.0=$ not stated). DeJong and BurgessProctor considered states where respondents are statutorily prohibited from possessing a weapon to be the most victim-friendly.

\section{Analytic Procedure}

Content analysis was conducted using Atlas.ti7, a qualitative software data management and organization suite (Muhr, 2013). Each state's PPO statute was uploaded into an Atlas.ti database and coded by one of two researchers using DeJong and BurgessProctor's (2006) coding scheme. Once statutes were coded, the numerical score for each item in DeJong and Burgess-Proctor's (2006) coding scheme was entered into SPSS. Both researchers then coded three additional statutes, and interclass correlations (ICCs) were estimated to determine the interrater reliability of coding (using a total of $n=6$ statutes). The results of the ICCs demonstrated a correlation of 1 exhibiting perfect agreement across coders 1 and 2.

\section{Results}

\section{Victim-Friendliness Scores: Comparing 2003 With 2014}

As noted above, each state's 2014 PPO statute was examined for victim-friendliness using DeJong and Burgess-Proctor's (2006) coding scheme and overall victim-friendliness scores were calculated. The coding scheme included four domains: adherence to VAWA, petitioner-respondent relationship, administrative process, and punishing violations. Results suggested that states' victim-friendliness scores increased over the past decade (see Table 1). States' 2014 victim-friendliness scores ranged from 5.5-10 and the median victim-friendliness score was 8.0. Comparatively, in 2003 scores ranged from 4-10 and the median score was 6.0. More specifically, findings demonstrated that 39 states and the District of Columbia ${ }^{1}(76 \%)$ experienced positive changes 


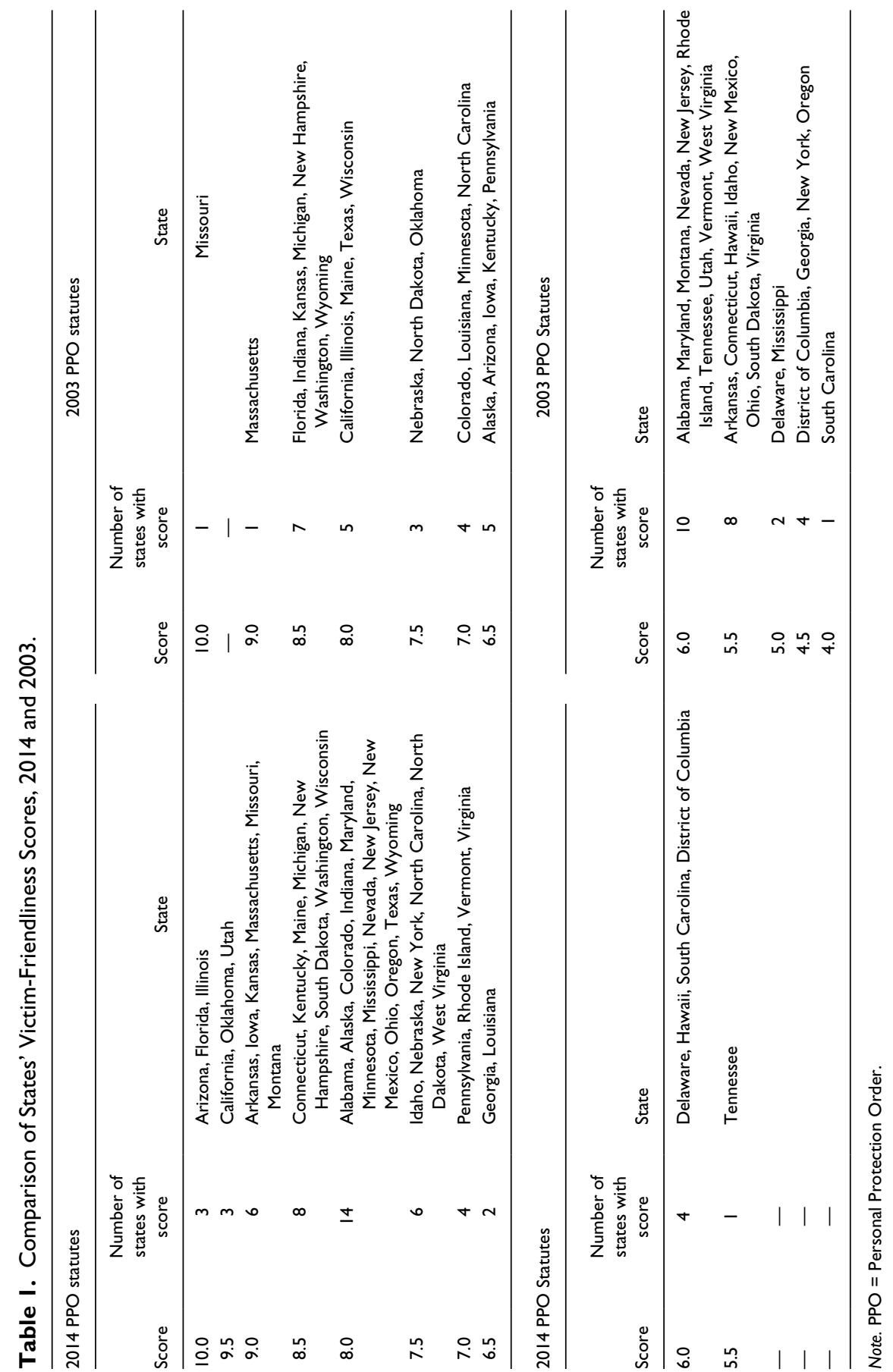


in their victim-friendliness scores from 2003-2014. Arkansas, Arizona, Oregon, and Utah experienced the greatest positive change in their ranking, yielding 2014 victimfriendliness scores that were 3.5 points higher than their 2003 scores. Five states ${ }^{2}$ experienced a negative change in their victim-friendliness score, and seven states' ${ }^{3}$ scores did not change from 2003.

In addition to calculating each state's 2014 victim-friendliness score, states were also assessed using DeJong and Burgess-Proctor's (2006) ranking system (low: 4.05.5; medium: 6.0-7.0; high: 7.5-10.0), and comparisons between states' 2003 and 2014 rankings are presented (see Figure 1). In 2014, 40 states ranked in the highest category of victim-friendliness; 10 states and the District of Columbia ranked in the middle category; and one state, Tennessee, ranked in the lowest category. Comparatively, in 2003, 17 states ranked in the highest category for victim-friendliness, 19 ranked in the middle category, and 15 states and the District of Columbia ranked in the lowest category.

\section{What Makes a State Victim-Friendly in 2014 Compared With 2003?}

VAWA. DeJong and Burgess-Proctor (2006) included two variables regarding whether PPO language adhered to VAWA: whether foreign orders were given full faith and credit and under what circumstances states utilized mutual PPOs. In 2014, 49 states and the District of Columbia included language around accepting and enforcing foreign orders, an increase of six states and the District of Columbia since 2003. The language regarding full faith and credit of PPOs was similar across all state statutes. For example, the Idaho statute reads,

A law enforcement officer of this state, upon determining that there is probable cause to believe that a valid foreign protection order exists and that the order has been violated, shall enforce the order as if it were the order of a tribunal of this state. Presentation of a foreign protection order that identifies both the protected individual and the respondent and, on its face, is currently in effect constitutes probable cause to believe that a valid foreign protection order exists. For the purposes of this subsection, the foreign protection order may be inscribed on a tangible medium or may have been stored in an electronic or other medium if it is retrievable in perceivable form. Presentation of a certified copy of a foreign protection order is not required for enforcement. (ID Penal Code $\S 39-6306 \mathrm{~A}$ (3) (g)(ii)(4)(a)

As seen above, states' statutes were prescriptive in their mandate to responding officers that foreign orders shall be interpreted as valid (a) on their face, (b) across multiple formats (e.g., in print or in electronic form), and (c) with or without their registration/certification.

The lone state that did not include such language in its PPO statute, either in 2003 or 2014, was New Jersey; however, it may be assumed that New Jersey intends to enforce foreign orders since federal statutes (e.g., VAWA) override state statutes. Furthermore, while five states (Alaska, Arkansas, Connecticut, Massachusetts, and 


\section{States Ranking in 2014}

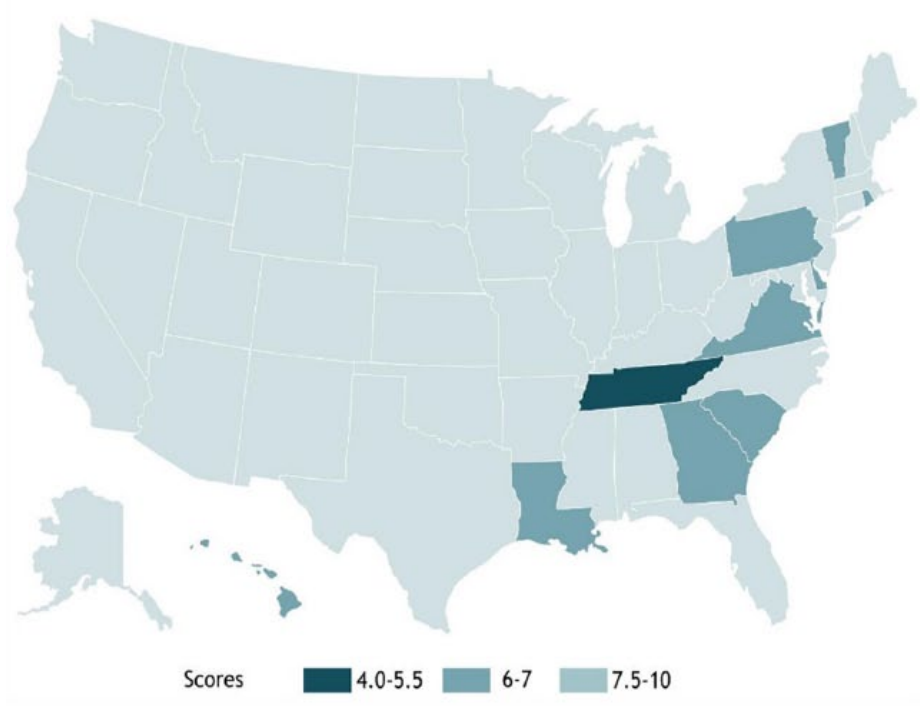

\section{States Ranking in 2003}

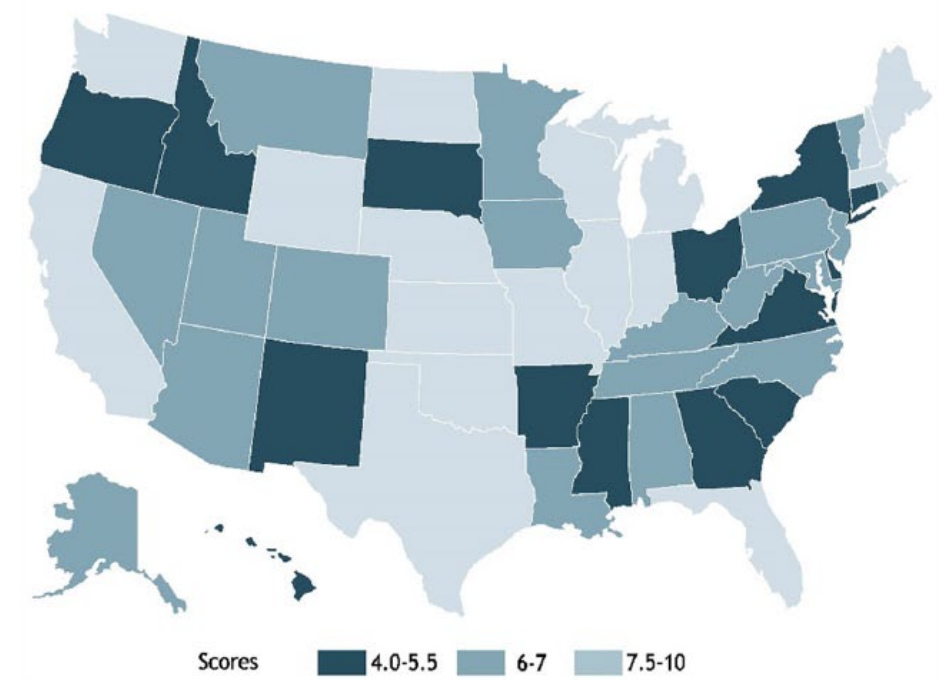

Figure I. State rankings in victim-friendliness score in 2014 and 2003. 
Pennsylvania) did not mention protocols around foreign protective orders, they did mention foreign orders in the context of a PPO violation. Thus, again, it may be inferred that these states will enforce foreign orders.

At the same time, as noted by DeJong and Burgess-Proctor (2006), the omission of direct language in states' PPO statutes regarding enforcement of foreign orders may lead to confusion by law enforcement officers regarding whether a PPO from another state or tribal area is valid in their state, and result in irregular enforcement of foreign PPOs. The proliferation of clear language regarding the validity of foreign PPOs is necessary as many victims may choose to relocate in their pursuit of freedom from abusive partners, or in cases where victims are financially dependent on their abuser and may be forced to relocate to live with or near family or friends.

In addition, under VAWA, states are not required to grant mutual PPOs or enforce mutual PPOs issued by other states. In 2014, 39 states - an increase from 30 states in 2003 - identified that mutual PPOs were only appropriate in cases where individuals applied for the order separately and presented evidence that the violence was in fact mutual. Many states have adopted similar language outlining the circumstances where mutual PPOs are appropriate. For example, Colorado's statute reads,

A court shall not grant a mutual protection order to prevent domestic abuse for the protection of opposing parties unless each party has met his or her burden of proof as described in section 13-14-104.5 (7) and the court makes separate and sufficient findings of fact to support the issuance of the mutual protection order to prevent domestic abuse for the protection of opposing parties. (CO Penal Code § 13-14-106(3)

Comparatively, 12 states $^{4}$ and the District of Columbia were silent on the issue of mutual protective orders, a substantial decrease from 2003 when 21 states were silent regarding the issuance of mutual PPOs.

Clear information delineating the circumstances where a mutual restraining order is appropriate is important given the real risk of an abuser's threat or actual use of "crossfiling" to control victims (Goodmark, 2004; Tarr, 2003). Regarding cross-filing among perpetrators, Goodmark (2004) explained that victims may face a petition from their abuser 'that mirrors the victims' but for one important detail: all of her allegations have suddenly happened to him, perpetrated by her" (p. 24). As previously mentioned, given that mutual protective orders do not delineate between the victim and the offender, and violation of the order by either party may result in punishment of both parties, the use of mutual PPOs increases the likelihood that victims will be punished. Furthermore, while PPOs are civil orders, a violation of a PPO can result in a felony charge. As described by Goodmark, "one fabricated charge of violation of a civil protection order could culminate with a battered woman facing criminal charges because she sought protection for herself' (p. 24). In addition to a potential felony record, a violation of a civil protection order may also negatively impact a case involving custody and could have such far-reaching effects as a victim losing custody of her children (C. F. Klein \& Orloff, 1993). 
Petitioner-respondent relationship. Two variables regarding petitioner-respondent relationship were assessed: whether victims of same-sex relationship violence were eligible for a PPO and whether the PPO statute used gender-neutral language. Analysis of 2014 PPO statutes reveal that no state explicitly indicates that individuals in samesex relationships may apply for a PPO. At the same time, 48 states and the District of Columbia use ambiguous language regarding the types of relationships covered by the PPO statute. The omission of specific language around same-sex couple applications may be a case of "strategic ambiguity" within statutes where lawmakers understand that legislation regarding a PPO statute overtly including same-sex couples would not be completely well received. This strategy may also help protect lesbian, gay, bisexual, transgender, and queer (LGBTQ) individuals in other parts of law because if same-sex relationships are explicitly listed in one part of law and not in another, individual decision-makers who hold anti-LGBTQ sentiments may refuse to grant protections under the nonexplicit part of the law. As same-sex marriage becomes legal in more states - as of August 31, 2014, same-sex marriage was legal in 18 states-the need for explicit inclusion diminishes as all states allow for spouses or ex-spouses to apply for PPOs, and the current "loophole" would remain for same-sex dating couples. At the same time, while petitioners in same-sex relationships may apply for a PPO in these states, the final decision for issuing a PPO is often left to an individual or individuals in the local jurisdiction, which may lead to disparate treatment.

Furthermore, two states (North Carolina and South Carolina) stipulate that only individuals from heterosexual relationships are eligible for PPOs. In contrast, in 2003 three states specified that PPO applicants must be individuals from heterosexual relationships (Delaware, Montana, and South Carolina; DeJong \& Burgess-Proctor, 2006). South Carolina's 2014 PPO remained unchanged from 2003: Only people in heterosexual relationships may apply for a PPO. Since 2003, North Carolina has changed its PPO statutory language so that PPOs are only available to those in a "personal relationship," where "personal relationship" is defined in part as ". . persons of the opposite sex who live together or have lived together" and "persons of the opposite sex who are in a dating relationship or who have been in dating relationships" (NC Penal Code $\S 50 \mathrm{~B}-1 \mathrm{~b}(2)(6))$. Results from the National Intimate Partner and Sexual Violence Survey (NISVS) indicate that partner violence occurs at similar rates among male and female individuals in LGBTQ relationships and their heterosexual counterparts (Breiding et al., 2014). In overtly excluding individuals in same-sex relationships from accessing PPOs, South Carolina and North Carolina seemingly leave victims who are experiencing abuse in same-sex relationships with unequal mechanisms for protection compared with heterosexual victims.

In 2014, all PPO statutes used gender-neutral language recognizing that petitioners (victims) as well as respondents (perpetrators) might be female or male. Comparatively, in 2003, many states referred to petitioners (victims) as she and to respondents (perpetrators) as he. However, in their previous analysis DeJong and Burgess-Proctor (2006) did note that such language was identified "in sections that ha[d] not been updated recently, and no state appear[ed] to use such language purposefully or to the detriment of victims" (p. 81). 
The use of gender-neutral language has important implications in the context of domestic violence among individuals in same-sex relationships as well as heterosexual relationships. According to the NISVS, approximately $35 \%$ of heterosexual males report experiencing violence within the context of an intimate relationship. At the same time, the use of gender-neutral language does not ensure that access to PPOs is gender neutral. The limited number of previous studies that have examined men's access to restraining orders suggests unequal access (Basile, 2005; Muller, Desmarais, $\&$ Hamel, 2009). For example, in an examination of a sample of male and female PPO applicants with similar injury rates in a rural Massachusetts court, Basile (2005) found that judges disproportionately denied men's requests for PPOs and were less likely to include provisions regarding firearms or custody in PPOs granted to men compared with women.

Administrative process. Four variables represented the PPO administrative process: (a) filing fees, (b) filing assistance, (c) PPO application independent of criminal charges, and (d) address confidentiality. Beginning with filing fees, while civil courts typically collect fees, many states understand that in the case of PPOs filing fees may create a financial barrier for victims and as a result may impact their safety. Thus, states generally handle filing fees in one of three ways. First, a state can choose to completely waive the filing fee for victims seeking PPOs. In 2014, 29 states waived fees entirely. Thus, low- and no-income victims of domestic violence in these states do not face financial barriers in accessing the PPO process. Second, states can choose to charge the fee to the respondent. Results showed that 21 states collected filing fees from the respondent. While this may seem like a form of justice for the victim, it may also have unintended negative consequences for the victim. The fee may provoke the abuser or may cause a decrease in the victim's financial resources if the abuser withholds financial support due to the court fee. Finally, states may charge a filing fee to the petitioner in cases of PPO applications just as they do other civil orders. In 2014, no state explicitly cited charging petitioners a filing fee for a PPO; however, Delaware's statute was silent on this issue. While DeJong and Burgess-Proctor (2006) cited the three aforementioned strategies for filing fees in 2003 PPO statutes, they did not provide detailed information regarding the number of states that utilized each strategy with the exception of stating that both Alabama and Georgia explicitly charged filing fees to the petitioner.

PPO forms and the courtroom process itself can be very confusing for people who have little to no experience working within the legal system. As such, some states allow the court clerk to assist petitioners. This assistance might range from simply ensuring that the petitioner has all the correct paperwork to providing nonlegal filling assistance. In 2014, there were 17 states $^{5}$ that did not mention any form of filing assistance; the other 34 states either mandated assistance or allowed for paperwork and instructional brochures to be distributed.

Statutory language that requires clerks to provide filing assistance with the PPO application ensures the greatest support for victims who are applying for a PPO. For example, Nevada required the clerk of the court to provide assistance: 
The clerk of the court or other person designated by the court shall assist any party in completing and filing the application, affidavit and any other paper or pleading necessary to initiate or respond to an application for a temporary or extended order. This assistance does not constitute the practice of law, but the clerk shall not render any advice or service that requires the professional judgment of an attorney. (NRS § 33.050(3))

Comparatively, states that only specified that the court should provide the correct paperwork for PPOs included language like that of Kansas: "the clerk of the court shall supply the forms for the petition and orders, which shall be prescribed by the judicial council" (KKRS $\S 60-3104$ ). While being directed to the proper paperwork may be helpful, the legal jargon embedded in such paperwork as well as the multistep process involved in filing a PPO is often quite complicated for victims to navigate alone. In this vein, in addition to the current options for assistance, some prior research indicates that access to legal assistance is an important factor in the PPO process (Durfee, 2009).

Finally, one state, Nebraska, specifically forbade filing assistance. Nebraska's code stated that the "clerk and his or her employees shall not provide assistance in completing the forms" (NE Penal Code $\S$ 42-924.02). Comparatively, in 2003 all states either required court staff to assist petitioners or were silent on the issue; no states specifically disallowed filing assistance (DeJong \& Burgess-Proctor, 2006).

Many victims seeking PPOs do not want to seek criminal action or do not meet the criteria for a criminal case (e.g., lack of evidence, domestic violence that is primarily nonphysical abuse; Candela, 2016; Ko, 2002; Waul, 2000), so access to PPOs independent of the criminal process is imperative. Ascertaining whether or not 2014 PPO statutes allowed petitioners to file for a PPO separate from criminal charges was problematic, a difficulty that DeJong and Burgess-Proctor (2006) also experienced in their analysis of 2003 PPO statutes. In 2014, 41 state statutes specified that a PPO was obtainable in addition to other remedies like divorce or criminal charges, but did not explicitly state whether the other remedies were mandatory. Only Alabama's statute explicitly allowed for PPO application outside of other remedies: ". . . a protection order may be requested in any pending civil or domestic relations action, as an independent civil action, or in conjunction with the preliminary, final, or post-judgment relief in a civil action" (AL Penal Code $\S 30-5-3$ ). The 10 remaining states were silent on the range of remedies available.

The ability to keep a victim's address confidential is important for victim safety. If a victim has fled to a shelter or another undisclosed location, they may feel that the danger of their abuser knowing their address outweighs the potential safety that a PPO may provide. In 2014, 43 states provided victims access to a confidential address program. Typically, an address confidentiality program allows a victim to use a P.O. Box address assigned to the program coordinator, and then the coordinator sends the mail to the victim's confidential address. Eight states' ${ }^{6} 2014$ PPO statutory language was silent on this issue. In DeJong and Burgess-Proctor's (2006) analysis of 2003 statutes, states had yet to develop formal address confidentiality programs. Their results did indicate that victim confidentiality was "protected in several ways" (p. 82) but did not provide numerical results regarding these strategies, state breakdowns, or examples. 
Punishing violations. Overall, in 2003 and 2014 the vast majority of states charged all PPO violations as misdemeanors: 46 states and 37 states, respectively. Two states, Connecticut and Arizona, charged the first violation of a PPO as a felony. Comparatively, in 2003, Connecticut and Maine were the two states to charge the first violation of a PPO as a felony (DeJong \& Burgess-Proctor, 2006), but since 2003, Maine has changed its statute so that any violation of a PPO is a misdemeanor. In addition, in 2014, 12 states $^{7}$ charged the first PPO violation as a misdemeanor and subsequent violations as a felony. Comparatively, in 2003, only three states, Missouri, Nebraska, and North Dakota, charged the first violation of a PPO as a misdemeanor and subsequent violations as a felony (DeJong \& Burgess-Proctor, 2006).

This research also uncovered that many states' 2014 PPO statutes mandate penalty enhancements for subsequent PPO violations, an aspect not examined by DeJong and Burgess-Proctor (2006). For example, in Maryland, while each convicted violation of a PPO is charged as a misdemeanor, regarding punishment for violations, "for a first offense, a fine not exceeding $\$ 1000$ or imprisonment not exceeding 90 days or both; and for a second or subsequent offense, a fine not exceeding $\$ 2500$ or imprisonment not exceeding 1 year or both" (MD Penal Code $\S 4-509$ ). However, while prior research estimates that an average of $40 \%$ (Spitzberg, 2002), and as many as $70 \%$ of women with a PPO experience a PPO violation (Carlson, Harris, \& Holden, 1999; Harrell \& Smith, 1996; Keilitz et al., 1997; Logan, Shannon, Walker, \& Faragher, 2006; McFarlane et al., 2004; Tjaden \& Thoennes, 2000), it is unclear whether increased sanctions or penalty enhancements for PPO violations are associated with lower rates of PPO violations.

In addition to criminal justice sanctions, states often either allow for or mandate counseling or other treatment for the abuser in an effort to encourage rehabilitation. In 2014, 34 states $^{8}$ referenced treatment as an optional remedy for a PPO violation. For example, Tennessee's statute stated,

A protection order granted under this part to protect the petitioner from domestic abuse, stalking, or sexual assault may include, but is not limited to: directing the respondent to attend available counseling programs that address violence and control issues or substance abuse problems. (TN Penal Code $\S 36-6-606$ (a)(8))

In comparison, eight states ${ }^{9}$ mandated the use of treatment upon a PPO violation. Hawaii's statute read, "a person convicted under this section shall undergo domestic violence intervention at any available domestic violence program as ordered by the court" (HI Penal Code $\S 586-4(4)(e)$ ). In 2003, only 16 states ${ }^{10}$ referenced treatment as an option and two states, Massachusetts and Nevada, mandated counseling upon a violation of a PPO (DeJong \& Burgess-Proctor, 2006).

The surge in the utilization of batterer intervention treatment and/or counseling for abusers upon violation of a PPO is consistent with the overall proliferation of BIPs in the United States with estimates suggesting that more than half a million men enroll in approximately 2,500 BIPs each year (Boal \& Mankowski, 2014). At the same time, current research provides only moderate support for the impact of BIPs on domestic 
violence recidivism (Babcock, Green, \& Robie, 2004; Coulter \& VandeWeerd, 2009; Feder \& Wilson, 2005; Stover, Meadows, \& Kaufman, 2009). Given the lack of empirical support for BIPs, many jurisdictions have recognized the need to enhance and coordinate their response to domestic violence as a community. In one study, Shepard (1992) conducted a follow-up examination of a coordinated community response that included offenders participating in 22 weeks of treatment. Five years later, $15 \%$ of the offenders had been the subject of a protection order. According to Shepard there is "an urgent need to develop improved interventions for IPV offenders" (p. 15).

Finally, given that abusers' access to firearms can decrease victim safety-access to a firearm is consistently identified as a risk factor for femicide (Campbell et al., 2003) - many states mandate or provide for the (optional) removal of firearms upon the issuance of a PPO. In 2014, 17 states mandated firearm removal. ${ }^{11}$ West Virginia's statute stated that "... the protective order must prohibit the respondent from possessing any firearm or ammunition" (WV Penal Code $§ 48-27-502$ (b)). In addition, 23 total states ${ }^{12}$ allowed courts the option to remove firearms. When firearm removal was an option, the statute tended to use "may" language, which allows for judicial discretion (Greer \& Purvis, 2011). For example, Rhode Island's statute states, "After notice to the respondent and a hearing, the court in addition to any other restrictions, may order the defendant to surrender physical possession of all firearms in his or her possession, care, custody or control" (RI Penal Code $\S 15-15-3(5)$ ). Furthermore, in 11 states there was no mention of firearm removal. ${ }^{13}$

In 2003, eight states' PPO statutes ${ }^{14}$ required the removal of firearms and 15 states' ${ }^{15}$ PPO statutes allowed for the removal of firearms (DeJong \& Burgess-Proctor, 2006). Thus, there has been a shift in language regarding the removal of firearms in the context of PPOs with more states mandating or allowing courts the option to remove firearms from abusers. At the same time, such mandates may prove difficult to enforce without the offender's cooperation and a commitment to enforcement by both the court and local law enforcement. For example, research from Frattaroli and Teret (2006) found that law enforcement officers in Maryland reported that they had few options for enforcement if, upon serving a PPO with a firearm removal provision, a respondent denied possessing any firearms. In addition, a review of firearm removal in California found that few criminal justice agencies confiscated firearms from respondents subject to PPOs when firearms were not surrendered voluntarily (Seave, 2006). Further research in Los Angeles and New York found that judges failed to mandate that domestic violence offenders surrender their firearm during the PPO process, even in light of the fact that in most cases victims specifically asked for their abusers to be disarmed (Webster et al., 2010). As such, increased provisions regarding firearm removal does not necessarily indicate that there has been an increase in the actual removal of firearms from abusers.

\section{Conclusion and Directions for Future Research}

Based on DeJong and Burgess-Proctor's (2006) conceptualization of victim-friendliness, over three quarter of states' 2014 PPO statutes were determined to be at least 
moderately victim-friendly. At the same time, while the current research provides an examination of victim-friendliness within the PPO statutory language, the extent to which individual provisions are included in the Orders provided to victims, and/or whether provisions are enforced by local law enforcement, was beyond the scope of the present study. As a result, it may be that states' PPO statutes are victim friendly on paper, but not in practice. One direction for future research might be to compare the provisions included in PPOs granted to victims to the provisions allowed under the state statute as well as victims' self-reported PPO violations reported to law enforcement compared with violations that are investigated and/or upheld by the court.

Furthermore, it is unclear whether PPO victim-friendliness impacts victims' satisfaction with PPOs or whether PPO statutes in specific states are more or less effective than those in others. Future research might also include exploring the very conceptual framework from which PPO statutes are examined. For example, Cattaneo and Goodman (2015) noted that evaluating the effectiveness of PPOs typically involves measuring success according to subsequent recidivism; however, such an approach does not consider additional goals that victims may have when seeking the Order. Some research suggests that the PPO process can facilitate victim empowerment, even if victims still experience violence from their partner (Grau et al., 1985; Harrell \& Smith, 1996; Joice, 2006). According to preliminary findings reported by Goodman and colleagues (2016), victims who sought orders of protection felt more empowered in their decision-making and were more likely to end their relationship than victims who did not seek out PPOs. As such, the PPO process may represent an avenue for victims to assert control against their abusers.

Guided by the literature, scholars might consider expanding DeJong and BurgessProctor's (2006) concept of victim-friendliness to include indicators of victim empowerment. States with statutes promoting victim autonomy and with greater opportunities for the power dynamics to shift from the abuser and/or the state to the victim would likely facilitate victim empowerment. Currently, in regard to states' PPO statutory language, the relationship between victim-friendliness and victim empowerment is unknown.

Given the extent to which PPOs are used in response to domestic violence in the United States, continued focus on "what works" to meet victims' needs is essential. As usual, longitudinal research is necessary to examine the long-term impacts of PPOs and other legal remedies for victims of domestic violence. This research, as suggested by Logan, Walker, Shannon, and Cole (2008), should differentiate between victim/abuser relationship(s): whether the couple has separated, intends to separate, or intends to stay together, as the results may vary. In addition, longitudinal research should take into account the differences that might exist between heterosexual relationships and relationships in which one or more individuals identify with the LGBTQ community. The results from this research will allow lawmakers and advocacy programs alike to work with victims to create more individualized solutions to address domestic violence.

Finally, research must continue to focus on the role of criminal justice system and community-based solutions in preventing domestic violence across communities. State 
control of PPO violations may seem more dangerous to communities of color than community-based solutions, as the PPO process might result in additional surveillance from child welfare or immigration services (Ruttenberg, 1994). In continuing to refine response(s) to domestic violence, there must be equal attention paid to the impact of racism, homophobia, classism, and sexism. By doing this, more victims will be empowered to access a variety of tools to address the violence in their lives.

\section{Appendix}

Coding Scheme for 2014 PPO Statutes

\begin{tabular}{|c|c|}
\hline Variable & Coding scheme \\
\hline \multicolumn{2}{|l|}{ Violence Against Women Act } \\
\hline $\begin{array}{l}\text { Full faith and credit of foreign } \\
\text { PPOs }\end{array}$ & $\begin{array}{l}0=\text { not stated } \\
.5=\text { upon registration/implied } \\
\mathrm{I}=\text { yes }\end{array}$ \\
\hline Allows for mutual PPOs & $\begin{array}{l}0=\text { not stated } \\
.5=\text { implied }, \text { but not stated explicitly } \\
I=\text { mutual orders not allowed without proof }\end{array}$ \\
\hline \multicolumn{2}{|l|}{ Petitioner-respondent relationship } \\
\hline Same-sex couples eligible for PPO & $\begin{array}{l}0=\text { no } \\
1=\text { yes }\end{array}$ \\
\hline Use of gender-neutral language & $\begin{array}{l}0=\text { no } \\
1=\text { yes }\end{array}$ \\
\hline \multicolumn{2}{|l|}{ Administrative process } \\
\hline Court clerk provides assistance & $\begin{array}{l}0=\text { no } / \text { not stated } \\
\mathrm{I}=\text { yes }\end{array}$ \\
\hline Status of PPO filing fees & $\begin{array}{l}0=\text { not stated/fees charged } \\
.5=\text { fees charged to respondent } \\
\mathrm{I}=\text { no fees charged to either party }\end{array}$ \\
\hline $\begin{array}{l}\text { PPO outside of filing criminal } \\
\text { charges }\end{array}$ & $\begin{array}{l}0=\text { no } \\
1=\text { yes }\end{array}$ \\
\hline $\begin{array}{l}\text { Victim's address can remain } \\
\text { confidential }\end{array}$ & $\begin{array}{l}0=\text { no } \\
1=\text { yes }\end{array}$ \\
\hline \multicolumn{2}{|l|}{ Punishing violations } \\
\hline Criminal justice implications & $\begin{array}{l}0=\text { any } \mathrm{PPO} \text { violation is a misdemeanor } \\
.5=\text { first } \mathrm{PPO} \text { violation is a misdemeanor } \\
\mathrm{I}=\text { any } \mathrm{PPO} \text { violation is a felony }\end{array}$ \\
\hline Role of Counseling & $\begin{array}{l}0=\text { not stated } \\
.5=\text { counseling } / \mathrm{BIP} \text { in an option for PPO violation } \\
\mathrm{I}=\text { counseling } / \mathrm{BIP} \text { is mandatory for PPO violation }\end{array}$ \\
\hline Firearm regulations restrictions & $\begin{array}{l}0=\text { not stated } \\
.5=\text { option in PPO } \\
I=\text { mandatory in PPO }\end{array}$ \\
\hline
\end{tabular}

Note. $\mathrm{PPO}=$ Personal Protection Order; BIP = batterer intervention treatment program. 


\section{Declaration of Conflicting Interests}

The author(s) declared no potential conflicts of interest with respect to the research, authorship, and/or publication of this article.

\section{Funding}

The author(s) received no financial support for the research, authorship, and/or publication of this article.

\section{Notes}

1. Alabama, Alaska, Arkansas, Arizona, California, Colorado, Connecticut, Delaware, District of Columbia, Florida, Georgia, Hawaii, Idaho, Illinois, Iowa, Kansas, Kentucky, Maine, Maryland, Minnesota, Mississippi, Montana, Nevada, New Jersey, New York, New Mexico, North Carolina, Ohio, Oklahoma, Oregon, Pennsylvania, Rhode Island, South Carolina, South Dakota, Utah, Vermont, Virginia, West Virginia, and Wisconsin.

2. Louisiana, Indiana, Tennessee, Missouri, and Wyoming.

3. Massachusetts, Michigan, Nebraska, New Hampshire, North Dakota, Texas, and Washington.

4. Connecticut, District of Columbia, Delaware, Hawaii, Louisiana, Minnesota, New Jersey, Oregon, Rhode, Island, Tennessee, Vermont, Virginia.

5. Colorado, Connecticut, District of Columbia, Hawaii, Idaho, Maryland, Massachusetts, Mississippi, New Hampshire, New Mexico, New York, North Dakota, Ohio, Rhode Island, Texas, Virginia, and West Virginia.

6. Alaska, District of Columbia, Georgia, Hawaii, North Dakota, South Carolina, South Dakota, and Tennessee.

7. Arkansas, Illinois, Kansas, Missouri, Nebraska, North Carolina, North Dakota, Oklahoma, South Dakota, Utah, Virginia, and Washington.

8. Alaska, Arizona, California, Colorado, Connecticut, District of Columbia, Delaware, Georgia, Idaho, Illinois, Iowa, Kansas, Kentucky, Maine, Maryland, Mississippi, Missouri, Montana, New Hampshire, New Jersey, New York, North Carolina, North Dakota, Ohio, Oregon, Rhode Island, South Dakota, Tennessee, Texas, Utah, Virginia, Washington, West Virginia, and Wyoming.

9. Colorado, Florida, Hawaii, Louisiana, Massachusetts, Minnesota, New Mexico, and Oklahoma.

10. Alabama, Arizona, Arkansas, Iowa, Michigan, Nebraska, New York, Oregon, Pennsylvania, South Carolina, South Dakota, Tennessee, Utah, Vermont, West Virginia, and Wisconsin.

11. Arkansas, California, Colorado, Connecticut, Florida, Hawaii, Illinois, Iowa, Maryland, Massachusetts, New Hampshire, New Jersey, Texas, Virginia, Washington, West Virginia, and Wisconsin.

12. Alabama, Alaska, Arizona, District of Columbia, Delaware, Indiana, Maine, Michigan, Minnesota, Montana, Nebraska, Nevada, New York, North Carolina, North Dakota, Ohio, Oklahoma, Oregon, Pennsylvania, Rhode Island, South Dakota, Tennessee, and Utah.

13. Georgia, Idaho, Kansas, Kentucky, Louisiana, Mississippi, Missouri, New Mexico, South Carolina, Vermont, and Wyoming.

14. California, Florida, Massachusetts, Michigan, New Hampshire, Texas, Utah, and Wisconsin.

15. Alaska, Arizona, Delaware, Illinois, Indiana, Maine, Maryland, Montana, New Jersey, New York, North Carolina, North Dakota, Oregon, Pennsylvania, and West Virginia. 


\section{References}

Alaggia, R., Regehr, C., \& Rishcynski, G. (2009). Intimate partner violence and immigration laws in Canada: How far have we come? International Journal of Law and Psychiatry, 32, 335-341.

Babcock, J. C., Green, C. E., \& Robie, C. (2004). Does batterers' treatment work? A meta-analytic review of domestic violence treatment. Clinical Psychology Review, 23, 1023-1053.

Bailey, J. E., Kellermann, A. L., Somes, G. W., Banton, J. G., Rivara, F. P., \& Rushforth, F. P. (1997). Risk factors for violent death of women in the home. Archives of Internal Medicine, 157, 777-782.

Bair-Merritt, M. H., Blackstone, M., \& Feudtner, C. (2006). Physical health outcomes of childhood exposure to intimate partner violence: A systematic review. Pediatrics, 117(2), e278-e290.

Basile, S. (2005). A measure of court response to requests for protection. Journal of Family Violence, 20, 171-179.

Berk, R. A., Berk, S. F., Loseke, D. R., \& Rauma, D. (1983). Mutual combat and other family violence myths. In D. Finkelhor, R. J. Gelles, G. T. Hotaling, \& M. A. Straus (Eds.), The dark side of families: Current family violence research (pp. 197-213). Beverly Hills, CA: Sage.

Black, M. C., Basile, K. C., Breiding, M. J., Smith, S. G., Walters, M. L., Merrick, M. R., et al. (2011). The National Intimate Partner and Sexual Violence Survey (NISVS): 2010 summary report. Atlanta, GA: National Center for Injury Prevention and Control, Centers for Disease Control and Prevention.

Boal, A. L., \& Mankowski, E. S. (2014). The impact of legislative standards on batterer intervention program practices and characteristics. American Journal of Community Psychology, 53, 218-230.

Brame, R., Kaukinen, C., Gover, A. R., \& Lattimore, P. K. (2015). No-contact orders, victim safety, and offender recidivism in cases of misdemeanor criminal domestic violence: A randomized experiment. American Journal of Criminal Justice, 40, 225-249.

Breiding, M. J., Smith, S. G., Basile, K. C., Walters, M. L., Chen, I., \& Merrick, M. T. (2014). Prevalence and characteristics of sexual violence, stalking, and intimate partner violence victimization: National Intimate Partner and Sexual Violence Survey, United States, 2011. Atlanta, GA: National Centers for Injury Prevention and Control, Centers for Disease Control and Prevention.

Burgess, A. W., Baker, T., Greening, D., Hartman, C., Burgess, A. G., Douglas, J. E., et al. (1997). Stalking behaviors within domestic violence. Journal of Family Violence, 12, 389403.

Campbell, J. C., Webster, D., Koziol-McLain, J., Block, D., Campbell, D., Curry, M. A., et al. (2003). Risk factors for femicide in abusive relationships: Results from a multisite case control study. American Journal of Public Health, 93, 1089-1097.

Candela, K. (2016). Protecting the invisible victim: Incorporating coercive control in domestic violence statutes. Family Court Review, 54, 112-125.

Carlson, M. J., Harris, S. D., \& Holden, G. W. (1999). Protective orders and domestic violence: Risk factors for re-abuse. Journal of Family Violence, 14, 205-226.

Cattaneo, L. B., \& Goodman, L. A. (2015). What is empowerment anyway? A model for domestic violence practice, research, and evaluation. Psychology of Violence, 5, 84-94.

Chaundhuri, M., \& Daly, K. (1992). Do restraining orders help? Battered women's experience with male violence and legal process. In E. Buzawa \& C. Buzawa (Eds.), Domestic 
violence: The changing criminal justice response (pp. 227-252). Westport, CT: Auburn House.

Coker, A. L., Davis, K. E., Arias, I., Desai, S., Sanderson, M., Brandt, H. M., \& Smith, P. H. (2002). Physical and mental health effects of intimate partner violence for men and women. American Journal of Preventive Medicine, 23, 260-268.

Coulter, M., \& VandeWeerd, C. (2009). Reducing domestic violence and other criminal recidivism: Effectiveness of a multi-level batterers intervention program. Violence and Victims, 24, 139-153.

Davis, R. C., \& Smith, B. (1995). Domestic violence reforms: Empty promises or fulfilled expectations? Crime \& Delinquency, 41, 541-552.

DeJong, C., \& Burgess-Proctor, A. (2006). A summary of Personal Protection Order statutes in the United States. Violence Against Women, 12, 68-88.

Durfee, A. (2009). Victim narratives, legal representation, and domestic violence civil protection orders. Feminist Criminology, 4, 7-31.

Eigenberg, H., McGuffee, K., Berry, P., \& Hall, W. H. (2003). Protective order legislation: Trends in state statutes. Journal of Criminal Justice, 31, 411-422.

Feder, L., \& Wilson, D. B. (2005). A meta-analytic review of court-mandated batterer intervention programs: Can courts affect abusers' behavior? Journal of Experimental Criminology, $1,239-262$.

Fernandez, M., Iwamoto, K., \& Muscat, B. (1997). Dependency and severity of abuse: Impact on women's persistence in utilizing the court system as protection against domestic violence. Women \& Criminal Justice, 9, 39-63.

Fischer, K., \& Rose, M. (1995). When “enough is enough": Battered women's decision making around court orders of protection. Crime \& Delinquency, 41, 414-429.

Fleury-Steiner, R. E., Miller, S. L., Maloney, S., \& Postel, E. B. (2016). "No contact, except ...": Visitation decisions in protection orders for intimate partner abuse. Feminist Criminology, 11, 3-22.

Frattaroli, S., \& Teret, S. P. (2006). Understanding and informing policy implementation: A case study of the domestic violence provisions of the Maryland Gun Violence Act. Evaluation Review, 30, 347-360.

Fritsche, O. M. (2014). The role of enticement in a violation of a protection order. Washington \& Lee Law Review, 71, 1473-1518.

Goldfarb, S. F. (2008). Reconceiving civil protection orders for domestic violence: Can law help end the abuse without ending the relationship? Cardozo Law Review, 29, 1487-1551.

Goodman, L. A., Thomas, K., Cattaneo, L. B., Heimel, D., Woulfe, J., \& Chong, S. K. (2016). Survivor-defined practice in domestic violence work measure development and preliminary evidence of link to empowerment. Journal of Interpersonal Violence, 31, 163-185.

Goodmark, L. (2004). Law is the answer? Do we know that for sure? Questioning the efficacy of legal interventions for battered women. Saint Louis University Public Law Review, 23(7), $7-48$.

Gover, A. R. (2011). New directions for domestic violence offender treatment standards: Colorado's innovative approach to differentiated treatment. Partner Abuse, 2, 95-120.

Gover, A. R., Kaukinen, C., \& Fox, K. A. (2008). The relationship between violence in the family of origin and dating violence among college students. Journal of Interpersonal Violence, 23, 1667-1693.

Grau, J., Fagan, J., \& Wexler, S. (1985). Restraining orders for battered women: Issues of access and efficacy. In C. SchWeber \& C. Feinman (Eds.), Criminal justice politics and women: The aftermath of legally mandated change (pp. 13-28). New York: The Haworth Press. 
Greer, B. T., \& Purvis, J. G. (2011). Judges going rogue: Constitutional implications when mandatory firearm restrictions are removed from domestic violence restraining orders. Wisconsin Journal of Law, Gender \& Society, 26, 275-312.

Gustafsson, H. C., \& Cox, M. J., \& Family Life Project Key Investigators. (2016). Intimate partner violence in rural low-income families: Correlates and change in prevalence over the first 5 years of a child's life. Journal of Family Violence, 31, 49-60.

Haggård, U., Freij, I., Danielsson, M., Wenander, D., \& Långström, N. (2017). Effectiveness of the IDAP treatment program for male perpetrators of intimate partner violence: A controlled study of criminal recidivism. Journal of Interpersonal Violence, 32, 1027-1043. doi: $10.1177 / 0886260515586377$

Harrell, A., \& Smith, B. E. (1996). Effects of restraining orders on domestic violence victims. In E. Buzawa \& C. Buzawa (Eds.), Do arrests and restraining orders work? (pp. 214-242). Thousand Oaks, CA: Sage.

Hien, D., \& Ruglass, L. (2009). Interpersonal partner violence and women in the United States: An overview of prevalence rates, psychiatric correlates and consequences and barriers to help seeking. International Journal of Law and Psychiatry, 32, 48-55.

Joice, V. J. (2006). A restraining order and a handgun: North Carolina's attempt to "empower" victims of domestic violence. Howard Law Journal, 50(1), 289-317.

Kaci, J. H. (1992). A study of protective orders issued under California's domestic violence prevention act. Criminal Justice Review, 17, 61-76.

Keilitz, S. L., Hannaford, P. L., \& Efkeman, H. S. (1997). Civil protection orders: The benefits and limitations for victims of domestic violence. Williamsburg, VA: National Center for State Courts.

Klein, A. R. (1996). Re-abuse in a population of court-restrained male batterers after two years: Development of a predictive model. In E. S. Buzawa \& C. G. Buzawa (Eds.), Do arrests and restraining orders work? (pp. 192-213). Thousand Oaks, CA: Sage.

Klein, C. F., \& Orloff, L. E. (1993). Providing legal protection for battered women: An analysis of state statutes and case law. Hofstra Law Review, 21, 801-899.

Ko, C. N. (2002). Civil restraining orders for domestic violence: The unresolved question of "efficacy." Southern California Interdisciplinary Law Journal, 11, 361-390.

Logan, T. K., Shannon, L., \& Walker, R. (2005). Protective orders in rural and urban areas: A multiple perspective study. Violence Against Women, 11, 876-911.

Logan, T. K., Shannon, L., Walker, R., \& Faragher, T. (2006). Protective orders: Questions and conundrums. Trauma, Violence, \& Abuse, 7, 175-205.

Logan, T. K., \& Walker, R. (2009). Civil protection order outcomes: Violations and perceptions of effectiveness. Journal of Interpersonal Violence, 24, 675-692.

Logan, T. K., \& Walker, R. (2010). Civil protective order effectiveness: Justice or just a piece of paper? Violence and Victims, 25, 332-348.

Logan, T. K., Walker, R., Shannon, L., \& Cole, J. (2008). Factors associated with separation and ongoing violence among women with civil protective orders. Journal of Family Violence, 23, 377-385.

Lucken, K., Rosky, J. W., \& Watkins, C. (2015). She said, he said, judge said: Analyzing judicial decision making in civil protection order hearings. Journal of Interpersonal Violence, 30, 2038-2066.

Max, W., Rice, D. P., Finkelstein, E., Bardwell, R. A., \& Leadbetter, S. (2004). The economic toll of intimate partner violence against women in the United States. Violence and Victims, $19,259-272$. 
McFarlane, J., Malecha, A., Gist, J., Watson, K., Batten, E., Hall, I., \& Smith, S. (2004). Protection orders and intimate partner violence: An 18-month study of 150 Black, Hispanic, and White women. American Journal of Public Health, 94, 613-618.

Meloy, J. R., Cowett, P. Y., Parker, S. B., Hofland, B., \& Friedland, A. (1997). Domestic protection orders and the prediction of subsequent criminality and violence toward protectees. Psychotherapy: Theory, Research, Practice, and Training, 34, 447-458.

Miller, N. (2004). Domestic violence: A review of state legislation defining police and prosecution duties and powers. Alexandria, VA: Institute for Law and Justice.

Mills, L. G. (1998). Mandatory arrest and prosecution policies for domestic violence: A critical literature review and the case for more research to test victim empowerment approaches. Criminal Justice and Behavior, 25, 306-318.

Muhr, T. (2013). Atlas.ti 5.0 software. Berlin, Germany: Scientific Software Development.

Muller, H. J., Desmarais, S. L., \& Hamel, J. M. (2009). Do judicial responses to restraining order requests discriminate against male victims of domestic violence. Journal of Family Violence, 24, 625-637.

National Center for Injury Prevention and Control. (2003). Costs of intimate partner violence against women in the United States. Atlanta, GA: Centers for Disease Control and Prevention.

National Center on Protection and Full Faith and Credit. (2010). Protection order relief matrix. Arlington, VA: Author.

Novello, A. C., Rosenberg, M., Saltzman, L., \& Shosky, J. (1992). A medical response to domestic violence. Journal of the American Medical Association, 267, 3132-3132.

Ooms, T. (2016). Policy responses to couple conflict and domestic violence: A framework for discussion. In A. Booth, A. C. Crouter, \& M. Clements (Eds.), Couples in conflict (pp. 227240). Mahwah, NJ: Lawrence Erlbaum.

Özçakar, N., Yeşiltepe, G., Karaman, G., \& Ergönen, A. T. (2016). Domestic violence survivors and their experiences during legal process. Journal of Forensic and Legal Medicine, 40, 1-7. doi:10.1016/j.jflm.2016.01.023

Pender, R. L. (2012). ASGW best practice guidelines: An evaluation of the Duluth model. Journal for Specialists in Group Work, 37, 218-231.

Price, J. H., \& Payton, E. (2016). Intimate partner firearms violence: A topic ignored in women's health journals and the impact on health providers. Violence and Gender, 3, 36-41. doi:10.1089/vio.2015.0016

Russell, B., Chapleau, K. M., \& Kraus, S. W. (2015). When is it abuse? How assailant gender, sexual orientation, and protection orders influence perceptions of intimate partner abuse. Partner Abuse, 6, 47-64.

Ruttenberg, M. H. (1994). Feminist critique of mandatory arrest: An analysis of race and gender in domestic violence policy. American University Journal of Gender, Social Policy \& the Law, 2, 171-199.

Seave, P. L. (2006). Disarming batterers through restraining orders: The promise and the reality in California. Evaluation Review, 30, 245-226.

Shepard, M. F. (1992). Predicting batterer recidivism five years after community intervention. Journal of Family Violence, 7, 167-178.

Spitzberg, B. H. (2002). The tactical topography of stalking victimization and management. Trauma, Violence, \& Abuse, 3, 261-288.

Stewart, D. E., Vigod, S., \& Riazantseva, E. (2016). New developments in intimate partner violence and management of its mental health sequelae. Current Psychiatry Reports, $18(1), 1-7$. 
Stout, K. D. (1989). Intimate femicide: Effect of legislation and social services. Affilia, 4(2), 21-30.

Stover, C. S., Meadows, A. L., \& Kaufman, J. (2009). Interventions for intimate partner violence: Review and implications for evidence-based practice. Professional Psychology: Research and Practice, 40, 223-233.

Tarr, N. W. (2003). The cost to children when batterers misuse order for protection statutes in child custody cases. Southern California Review of Law and Women's Studies, 13(35), 37-38.

Tjaden, P., \& Thoennes, N. (2000). Extent, nature, and consequences of intimate partner violence: Findings from the national violence against women survey (Publication No. NCJ 181867). Washington, DC: U.S. Department of Justice.

Violence Against Women Act [VAWA] (1994). 18 USCS § 2261 et seq. 1994.

Voris, M. J. (1991). The domestic violence civil protection order and the role of the court. Akron Law Review, 24, 423-432.

Waul, M. R. (2000). Civil protection orders: An opportunity for intervention with domestic violence victims. The Georgetown Public Policy Review, 6, 51-70.

Webster, D. W., Frattaroli, S., Vernick, J. S., O’Sullivan, C., Roehl, J., \& Campbell, J. C. (2010). Women with protective orders report failure to remove firearms from their abusive partners: Results from an exploratory study. Journal of Women's Health, 19, 93-98.

Weissman, D. M. (2007). The personal is political—and economic: Rethinking domestic violence. Brigham Young University Law Review, 2007, 387-449.

Wolfe, D. A., Crooks, C. V., Lee, V., McIntyre-Smith, A., \& Jaffe, P. G. (2003). The effects of children's exposure to domestic violence: A meta-analysis and critique. Clinical Child and Family Psychology Review, 6, 171-187.

World Health Organization. (2013). Global and regional estimates of violence against women: Prevalence and health effects of intimate partner violence and non-partner sexual violence. Geneva, Switzerland: Department of Reproductive Health and Research, World Health Organization. Retrieved from http://apps.who.int/iris/bitstream/10665/85 239/1/9789241564625_eng.pdf?ua=1

Zeoli, M., Malinski, R., \& Turchan, B. B. (2016). Risks and targeted interventions: Firearms in intimate partner violence. Epidemiology Review, 38, 125-139. doi:10.1093/epirev/mxv007

Zoellner, L. A., Feeny, N. C., Alvarez, J., Watlington, C., O’Neill, M. L., Zager, R., \& Foa, E. B. (2000). Factors associated with completion of the restraining order process in female victims of partner abuse. Journal of Interpersonal Violence, 15, 1080-1099.

\section{Author Biographies}

Tara N. Richards is an associate professor of criminal justice at the University of Baltimore. Her primary areas of research include intimate partner violence, sexual assault, and the role of gender in criminal justice system processes. Richards's scholarly work has appeared in journals such as Child Abuse and Neglect, Crime and Delinquency, and Law and Human Behavior and she is the co-editor of the book, Sexual Victimization: Then and Now.

Alison Tudor received her Bachelor of Science from the University of Florida in 2005 and her Master's of Public Administration from the University of Colorado Denver in 2015. She is the executive director of a multidisciplinary service organization in California that serves victims of domestic violence, sexual assault, and human trafficking, youth, youth in the dependent and delinquency systems, the homeless community, and people with substance use disorder. 
Angela R. Gover is a professor of criminology and criminal justice in the School of Public Affairs at the University of Colorado Denver. Her research focuses on interpersonal violence, gender and crime, victimization, domestic violence offender treatment, and system responses to interpersonal violence. She has published over 100 refereed articles and book chapters on topics related to crime and victimization. She has received numerous university and national awards for her efforts toward research, teaching, and service. Her current research examines the relationship between domestic violence offender treatment content and offender outcomes in Colorado. 